\title{
The effects of vitamin D supplementation on endogen amylin hormone, hormonal and biochemical parameters, and insulin resistance in type-2 diabetic patients with vitamin $D$ deficiency in the Kurdistan Region of Iraq.
}

\author{
Mudhafar Mohamed M. Saeed ${ }^{1}$, Abdulqader Asees Al-Naqshabandi ${ }^{1}$ \\ and Hawri Fatih Sami Aldawoodi ${ }^{2}$ \\ ${ }^{1}$ College of Pharmacy, Hawler Medical University, Erbil, Kurdistan region, Iraq. \\ ${ }^{2}$ Department of Biology, College of Science,Cihan University, Erbil, Kurdistan region, \\ Iraq.
}

Key words: vitamin D; amylin; HbA1c; insulin; C-peptide.

Abstract. The present study was conducted to evaluate the correlations between vitamin $\mathrm{D}$, amylin, e-peptide, insulin, and $\mathrm{HbA1c}$ and determine the effects of vitamin D supplementation on the level of these biomarkers in type-2 diabetic patients with vitamin D deficiency. A total of 87 Kurdish type- 2 diabetic patients participated in this clinical trial in which biomarkers, including vitamin $\mathrm{D}$ (25 hydroxy cholecalciferol), serum amylin, c-peptide, insulin, fasting blood glucose, HbA1c, HDLc, LDLc, total cholesterol, triglycerides, weight, height, waist circumference, and inflammation markers (i.e. IL6, TNF- $\alpha$, and hsCRP) were measured. Serum levels of vitamin D were positively correlated with serum Amylin, e-peptide, insulin, and HDL, while it had negative correlations with HbA1c, fasting blood sugar, IL6, TNF- $\alpha$, hs-CRP, LDL, and triglycerides. After 14 weeks of supplementation with vitamin D (5000 IU/day) there were significant increases in plasma amylin, c-peptide, and insulin concentrations; but the levels of HbA1c, fasting blood glucose, TNF- $\alpha$, hs-CRP, and IL6 were significantly decreased. It can be concluded that vitamin D supplementation can potentially regulate blood glucose by activating the secretory function of pancreatic B-cells and reducing insulin resistance through a significant reduction in a circulatory level of inflammatory markers.

Corresponding author: Mudhafar Mohamed M. Saeed, College of Pharmacy, Hawler Medical University, Erbil, Kurdistan region, Iraq. Email: Mudhafar.pharm@gmail.com 


\section{Efectos de la suplementacion de Vitamina D sobre la hormona endógena amilina, parámetros hormonales y bioquímicos, $e$ insulina resistencia en pacientes diabéticos tipo 2 con deficiencia de Vitamina $D$ en la región Kurdistan de Irak.}

Invest Clin 2019; 60 (4): 310-318

Palabras clave: vitamina D; amilina; HbA1c; insulina; péptido-C.

Resumen. El presente estudio se realizó para evaluar las correlaciones entre la vitamina D, la amilina, el péptido C, la insulina y la HbA1c y determinar los efectos de la suplementación con vitamina $\mathrm{D}$ en el nivel de estos biomarcadores en pacientes diabéticos tipo 2 con deficiencia de vitamina D. Un total de 87 pacientes kurdos, diabéticos tipo 2, participaron en este ensayo clínico en el que se midieron los biomarcadores, incluídos la vitamina D (25 hidroxicolecalciferol), amilina sérica, péptido $\mathrm{C}$, insulina, glucosa sérica en ayunas, HbA1c, HDLc, LDLc, colesterol total, triglicéridos, peso, altura, la circunferencia de la cintura y los marcadores de inflamación (es decir, IL6, TNF- $\alpha$ y hs-CRP). El nivel sérico de vitamina $\mathrm{D}$ se correlacionó positivamente con la amilina sérica, el péptido $\mathrm{C}$, la insulina y el HDLc, mientras que tuvo correlaciones negativas con HbA1c, glucosa en sanǵre en ayunas, IL6, TNF- $\alpha$, hs-CRP, LDLc y triǵlicéridos. Después de 14 semanas de suplementación con vitamina D (5000 UI / día) hubo aumentos significativos en las concentraciones plasmáticas de amilina, péptido $\mathrm{C}$ e insulina; pero los niveles de HbA1c, glucosa en sangre en ayunas, TNF- $\alpha$, hs-CRP e IL6 disminuyeron significativamente. Se puede concluir que la suplementación con vitamina $\mathrm{D}$ puede potencialmente regular la glucosa en la sangre activando la función secretora de las células B pancreáticas y reduciendo la resistencia a la insulina a través de una reducción signnificativa en un nivel circulatorio de marcadores inflamatorios.

Received: 25-02-2019 Accepted 16-10-2019

\section{INTRODUCTION}

A growing research evidence has concluded that type-2 diabetes (T2D) and its complications are significant causes of morbidity and mortality worldwide (1). As a crucial global health condition, 415 million people are afflicted with T2D, and it will increase to 642 million by 2040 (2). Vitamin D deficiency (a prohormone) is also considered as a public health problem throughout the world (3). Vitamin D is an essential fatsoluble secostroid responsible for the main- tenance of calcium homeostasis and good physical condition of the bone, and it has also been proved that this vitamin is associated with hypertension, diabetes, metabolic syndrome, cancer, and autoimmune and infectious diseases (4). Observational studies have indicated that vitamin $\mathrm{D}$ deficiency is associated with the onset of T2D, its progression, and subsequent macrovascular complications (5-9).

Amylin is a hormone composed of 37 -amino acid peptides. It is synthesized and co-localized with insulin in the beta-cells of

Vol. 60(4): 310 - 318, 2019 
pancreatic islets (10). Amylin is co-secreted with insulin from beta-cells of pancreatic islets in response to a meal ingestion. It is also an important hormone for energy balance regulation (11). Vitamin D deficiency has a negative impact on the level of amylin (12). Many clinical trials have been devoted to finding innovative methods for preventing and treating diabetes mellitus, and the focus of these trials has recently been on vitamin D supplementation. Mirhosseini et al. (13) found that vitamin $\mathrm{D}$ supplementation has a significant positive effect on fasting blood glucose (FBG), HbA1c, and homeostasis model assessment of insulin resistance (HOMAIR). The results of the studies conducted on both humans and animals have shown that vitamin $D$ status and insulin secretion and resistance are linked because both vitamin $D$ receptor and 1- $\alpha$-hydroxylase are present in the pancreatic $\beta$-cells (14). Based on the literature review, there is a constant association between increased body mass index and decreased serum vitamin $\mathrm{D}$ concentrations (15).

Chronic low-grade inflammation, commonly observed in obese patients, is correlated with the development of insulin resistance, which aggregates the risk of T2D (16). Recent data have shown that severe vitamin $\mathrm{D}$ deficiency is associated with increased levels of C-reactive protein (CRP), Tumor Necrosis Factor-alfa (TNF- $\alpha$ ), and IL- 6 (17).

Regarding the high prevalence of T2D among Kurds as well as the premise that T2D may present alongside vitamin $\mathrm{D}$ deficiency, the present investigation was aimed to:

1- Conduct an open-label clinical-analytical study on the effects of improved vitamin D status on insulin and amylin secretion, insulin resistance, insulin sensitivity, and pancreatic $\beta$-cell functions; 2 - evaluate the effect of vitamin D supplementation on the level of Amylin in T2D Kurdish patients (because amylin is a potential hormone in energy expenditure and glucose hemostasis, although it has been ignored in recent stud- ies); and 3- evaluate the effects of vitamin D supplementation on inflammatory markers in patients with both T2D and vitamin D deficiency.

\section{MATERIAL AND METHODS}

To take ethical considerations into account, necessary approval was obtained from the Ethical Committee of the Hawler Medical University prior to the beginning of the study. Moreover, all of the participants filled out a written informed consent and they were all free to leave the study at any phase. The study was conducted in the Endocrinology Center located in Sulaymaniyah Governorate, Iraq from December 1, 2017, to June 1, 2018. The Clinical Analysis Department of the College of Pharmacy of Hawler Medical University cooperated to conduct the study. Adult type-2 diabetic patients with vitamin $\mathrm{D}$ deficiency were enrolled in the present study. They were of both genders and aged 40 and over. The exclusion criteria consisted of having malnutrition, terminal illnesses, coronary artery, kidney or hepatic disease. Furthermore, pregnant and nursing patients with serum C-reactive protein (CRP) $\geq 6$ $\mathrm{mg} / \mathrm{L}$ were excluded from the study.

The target patients were enrolled in the Endocrinology Center in Sulaymaniyah Governorate, Iraq. Located in the Northern part of Iraq, Sulaymaniyah is a mountainous governorate characterized by its cold winters, and less sunlight exposure. Each patient was examined by an endocrinologist and the researcher's team. A total of 87 patients (15 males and 72 females) who met the abovementioned inclusion and exclusion criteria were enrolled for 14 weeks of vitamin D supplementation (5000 IU/day), which was added to their treatment regimens. At the beginning of the intervention, the participants were advised to contact the research staff immediately whenever their body reacted unexpectedly to the supplements.

Before and after supplementation with vitamin $\mathrm{D}_{3}$, the patients underwent an an- 
thropometric evaluation including height $(\mathrm{m})$, weight (kg), and waist circumference (cm) measurements.

Moreover, the Quetelet's equation (weight (kg)/height (m) 2) was utilized to calculate the patients' body mass index (BMI). Then, 12-hour overnight fasting venous blood samples were taken from them. The blood samples were divided into two parts; EDTA test tubes were filled with the first part in order to determine the glycosylated haemoglobin (HbA1c) percentage, and the non-coagulant test tubes were filled with the another part in which the sera were centrifuged to be separated $(3000 \mathrm{rpm}$ for 15 minutes), and they were kept at $-20^{\circ} \mathrm{C}$ for later measurements within 2 weeks of sampling.

Enzymatic reaction was also employed for spectrophotometric measurement of lipid profile $(\mathrm{mg} / \mathrm{dL})$ including total high- and low-density lipoprotein-cholesterol (HDLc \& LDL-c), triglyceride (TG), cholesterol (TC), and fasting serum glucose (FSG). Log of TG/HDL-e was calculated in order to determine the atherogenicity. Moreover, the technology of enzyme-linked immunosorbent assay (ELISA) was utilized to determine fasting serum insulin $(\mathrm{mU} / \mathrm{L})$, C-peptide (ng/ml), amylin ( $\mathrm{p} g / \mathrm{ml})$, IL6, TNF- $\alpha$, and hs-CRP. Homeostatic model assessment of insulin resistance (HOMA-IR) and Homeostatic model assessment of insulin sensitivity (HOMA-IS) was determined through the following formulas:

$$
\text { HOMA }-I R=\frac{\text { Fasting serum glucose }\left(\frac{m g}{d l}\right) \times \text { Fasting serum insulin }\left(\frac{m U}{L}\right)}{405}
$$

This study has some limitations including that it did not control for other potential confounders such as anti-diabetic oral agents, other pharmacological therapies and nutrition intervention.

\section{Statistical analysis}

The results are expressed as frequencies, percentages, and whenever possible as means \pm SD. Data were analyzed using independent and paired samples t-tests, chisquared and simple (rho) correlation tests. The level of statistical significance was considered $\mathrm{p}<0.05$; data analysis was conducted using SPSS version 21.0 software (IBM Corp., Armonk, N.Y., USA) and Microsoft Excel (2007).

\section{RESULTS}

The present study was conducted on 87 type-2 diabetic patients with a mean age of 50.5 years. The participants consisted of 72 females and 15 males. Regarding their marital status, all were married except two of them. Only four participants were smokers. Moreover, 44 patients had hypertension, and about $61 \%$ of them were living in rural areas (Table I).

After 14 weeks of intervention, vitamin D supplement resulted in a sharp improvement in the level of vitamin $\mathrm{D}$, which in turn led to a significant reduction in fasting blood glucose, and HbA1c, by a non-significant decrease in HOMA-IR. It also led to an improvement in the secretion of fasting serum insulin, and significant improvements were observed in C-peptide and amylin (Table II).

TABLE I

PATIENTS' DEMOGRAPHICS.

\begin{tabular}{|c|c|c|c|c|c|c|c|c|}
\hline \multicolumn{2}{|c|}{ Gender } & \multirow[b]{2}{*}{ Age \pm SD /year } & \multicolumn{2}{|c|}{ Marital status } & \multicolumn{2}{|c|}{ Residency } & \multirow{2}{*}{$\begin{array}{c}\text { Smoking } \\
\text { (No.) }\end{array}$} & \multirow{2}{*}{$\begin{array}{c}\text { Co-morbidity } \\
\text { (hypertension) } \\
\text { (No.) }\end{array}$} \\
\hline $\begin{array}{l}\text { Male } \\
\text { (No.) }\end{array}$ & $\begin{array}{c}\text { Female } \\
\text { (No.) }\end{array}$ & & $\begin{array}{c}\text { Single } \\
\text { (No.) }\end{array}$ & $\begin{array}{c}\text { Married } \\
\text { (No.) }\end{array}$ & $\begin{array}{c}\text { Urban } \\
\text { (No.) }\end{array}$ & $\begin{array}{l}\text { Rural } \\
\text { (No.) }\end{array}$ & & \\
\hline $15(17.24)$ & $72(82.76)$ & $50.5 \pm 7$ & $2(2.3)$ & $85(97.7)$ & $34(39.1)$ & $53(60.9)$ & $4(4.6)$ & $44(50.5)$ \\
\hline
\end{tabular}

The results are expressed as number (percentage) and mean \pm SD.

Vol. 60(4): 310 - 318, 2019 
TABLE II

ASSESSMENT OF GLYCAEMIC STATUS AND RELATED BIOMARKERS.

\begin{tabular}{lccc}
\hline Biomarkers & Before supplementation & After supplementation & P value \\
\hline Vitamin D $(\mathrm{ng} / \mathrm{mL})$ & $13.5 \pm 6.34$ & $33.21 \pm 10.14$ & $<0.001$ \\
Fasting serum ǵlucose $(\mathrm{mg} / \mathrm{dL})$ & $219.8 \pm 64.4$ & $176.6 \pm 55.9$ & \\
Glycated hemoǵlobin $(\mathrm{HbA1c} \%)$ & $9.9 \pm 1.52$ & $8.44 \pm 1.45$ & \\
Amylin $(\mathrm{pg} / \mathrm{mL})$ & $388.0 \pm 279.6$ & $426.0 \pm 309.1$ & \\
Fasting serum insulin $(\mu$ unit/mL) & $14.2 \pm 10.05$ & $16.56 \pm 10.08$ & \\
HOMA-IR & $8.0 \pm 7.36$ & $6.96 \pm 4$ & 0.125 \\
HOMA-IS & $0.125 \pm 5.6$ & $0.144 \pm 3.5$ & 0.09 \\
C-peptide $(\mathrm{ng} / \mathrm{mL})$ & $2.3 \pm 0.76$ & $2.97 \pm 0.9$ & 0.036 \\
\hline
\end{tabular}

The results are expressed as mean \pm SD. P-value represents the level of significant difference between pre-and posttreatment using two-tailed paired t-test. HOMA-IR: Homeostatic model assessment for insulin resistance. HOMA-IS: Homeostatic model assessment of insulin sensitivity.

Furthermore, after 14 weeks of the $5000 \mathrm{IU} /$ day vitamin D supplementation, the chronic low-grade inflammatory markers (high sensitivity C-reactive protein, interleukin 6 , and tumor necrosis factor- $\alpha$ ) decreased significantly (Table III).

Waist circumference (WC) and Body Mass Index (BMI) decreased significantly af- ter 14 weeks of vitamin D supplementation. Triglycerides, triǵlyceride to high-density lipoprotein ratio, and HDL also increased significantly. However, total cholesterol and LDL decreased after supplementation, but these differences were not significant (Table IV).

TABLE III

ASSESSMENT OF INFLAMMATORY MARKERS AND RELATED BIOMARKERS

\begin{tabular}{lccc}
\hline Biomarkers & $\begin{array}{c}\text { Before } \\
\text { supplementation }\end{array}$ & After supplementation & p-value \\
\hline High sensitivity C-reactive protein $(\mathrm{mg} / \mathrm{L})$ & $3.04 \pm 1.68$ & $2.53 \pm 1.42$ & \\
Interleukin 6 $(\mathrm{ng} / \mathrm{mL})$ & $198.3 \pm 84.8$ & $176.2 \pm 79.6$ & $<0.001$ \\
Tumor necrosis factor- $\alpha(\mathrm{ng} / \mathrm{mL})$ & $187.4 \pm 94.7$ & $169.3 \pm 95.2$ & \\
\hline
\end{tabular}

The results are expressed as mean \pm SD. P value represents the level of significant difference between pre-and posttreatment using two-tailed paired t-test.

TABLE IV

ANTHROPOMETRIC MEASUREMENTS AND FASTING LIPID PROFILE DATA

\begin{tabular}{lccc}
\hline Determinates & $\begin{array}{c}\text { Before } \\
\text { supplementation }\end{array}$ & $\begin{array}{c}\text { After } \\
\text { supplementation }\end{array}$ & P-value \\
\hline Waist circumference $(\mathrm{cm})$ & $100 \pm 6.5$ & $98.5 \pm 6.6$ & \\
Body mass index $(\mathrm{kg} / \mathrm{m} 2)$ & $25.7 \pm 2.9$ & $25.4 \pm 2.9$ & $<0.001$ \\
High & $38.1 \pm 11.8$ & $42.5 \pm 10.6$ & \\
Tríglycensity lipoprotein-cholesterol (mg/dL) & $4.6 \pm 3.288$ & $3.7 \pm 2.371$ & \\
Total cholesterol mg/dL) & $178.5 \pm 40$ & $176.8 \pm 37.5$ & 0.534 \\
Triǵlyceride (mg/dL) & $154.8 \pm 69.6$ & $143.4 \pm 65.2$ & 0.019 \\
Low density lipoprotein-cholesterol (mg/dL) & $117.6 \pm 31.5$ & $114.6 \pm 30.5$ & 0.278 \\
\hline
\end{tabular}

The results are expressed as mean \pm SD. P value represents the level of significant difference between pre-and posttreatment using two-tailed paired t-test. 


\section{DISCUSSION}

Considered as a global problem, vitamin $\mathrm{D}$ deficiency is observed in both tropical countries and those with temperate climate (18). Furthermore, vitamin D plays an important role in bone homeostasis. Data from observational studies have shown an association between vitamin D deficiency and chronic disorders such as diabetes, autoimmune and cardiovascular diseases (19). Type-2 diabetes is one of the leading non-communicable chronic diseases whose complications have become major causes of morbidity and mortality worldwide (1). It has also been indicated by observational studies, that there is an association between vitamin $\mathrm{D}$ deficiency and the onset and progression of T2D, as well as future macrovascular events (5-9). While, a randomized, double blind, placebo-controlled clinical trial among persons at high risk for T2D, found that vitamin D3 supplementation did not result in a significantly lower risk of diabetes than placebo (20).

In the present study, all of the patients had T2D and suffered from vitamin D deficiency. The effects of vitamin D supplement on glycemic status and chronic low-grade inflammatory markers in T2D were evaluated in this study. Vitamin D supplementation for 14 weeks considerably affected glycemic indices, insulin resistance, and systemic inflammation.

Findings of the present study demonstrated that vitamin D (5000 IU/day) supplementation resulted in a significant drop in the percentage of HbAlc and the level of fasting blood glucose, but it increased secretion of amylin and C-peptide remarkably and insulin non-significantly from pancreatic $\beta$-cells. Furthermore, the improved vitamin D level after supplementation (5000 IU/day) resulted in decreased HOMA-IR, which indieates the improvement in insulin sensitivity and decreased insulin resistance. Refined vitamin D status negatively affected the markers of inflammation through dropping the circulatory levels of IL6, TNF- $\alpha$, and hs-CRP. These results are along the lines of other related studies in which vitamin D supplementation improves insulin sensitivity (21) and reduces systemic inflammation(22).

Other study showed that supplementation with vitamin D for 12 weeks, compared with the placebo in patients with DFU, led to a significant reduction in HOMA-IR and HbA1c (23). Moreover, one-year 420 IU/day vitamin $\mathrm{D}$ supplementation increased serum $25(\mathrm{OH}) \mathrm{D}$ concentration, resulting in beneficial effects on fasting glucose level and insulin resistance (24). However, supplementation with $1000 \mathrm{IU} /$ day vitamin D among healthy overweight women for 12 weeks did not affect the insulin resistance (25).

In terms of inflammation, vitamin D supplementation reduced hs-CRP, IL-6, and TNF- $\alpha$ significantly, and this finding is consistent with other studies $(23,26-29)$. Matias et al. (30) also observed a significant reduction in the serum hs-CRP level at the one-year follow-up of patients with vitamin $\mathrm{D}$ deficiency who received high doses of vitamin D3. Although in a study conducted on patients with major depressive disorder, it was found that taking 50,000 IU/week vitamin D supplemention for 8 weeks did not affect hs-CRP level (31).

Witham et al. (32) found no reduction in the hs-CRP level after 8 weeks of supplementation with a single dose of $100,000 \mathrm{IU}$ vitamin D3 in women in southern Asia. Pittas et al. (33) also found no reduction in the CRP, interleukin 6 (IL-6), and tumor necrosis factor- $\alpha$ (TNF- $\alpha$ ) levels. Favorable effects of vitamin $\mathrm{D}$ intake on markers of insulin resistance can be explained through its impact on calcium and phosphorus metabolism as well as up-regulation of the insulin receptor gene and increased transcription of insulin receptor genes (34).

One of the strengths of the present study is the assessment of serum biomarkers related to $\beta$-cells function such as c-peptide, amylin and 25(OH)D. C-peptide secreted in equimolar concentration to insulin is widely 
considered as a better marker of residual $\beta$-cells function than insulin due to its longer half-life (35). In addition to C-peptide, amylin, as mentioned before, is a glucoregulatory hormone co-secreted with insulin in response to food intake to complement insulin dependent maintenance of postprandial glucose homeostasis (12). Interestingly, positive associations of insulin, C-peptide, and amylin with $25(\mathrm{OH}) \mathrm{D}$ were identified in the results of the present study.

Vitamin D supplementation (5000 IU daily) for 14 weeks led to a significant decrease in FBS and HbA1c by increasing the synthesis of amylin, insulin, and e-peptide. Furthermore, insulin resistance decreased, while insulin sensitivity increased as a result of the significant reduction in IL6 and TNF- $\alpha$.

\section{REFERENCES}

1. Islam SMS, Purnat TD, Phuong NTA, Mwingira U, Schacht K, Fröschl G. Noncommunicable diseases (NCDs) in developing countries: a symposium report. Global Health 2014; 10: 81. doi: 10.1186/s12992014-0081-9.

2. Ogurtsova K, Da Rocha Fernandes JD, Huang Y, Linnenkamp U, Guariguata L, Cho NH, Cavan D, Shaw JE, Makaroff LE. IDF Diabetes Atlas: Global estimates for the prevalence of diabetes for 2015 and 2040. Diabetes Res Clin Pract 2017; 128: 40-50.

3. Palacios C, Gonzalez L. Is vitamin D deficiency a major global public health problem? J Steroid Biochem Mol Biol 2014; 144: 138-145.

4. Hossein NA, Holick MF. Vitamin D for health: a global perspective. Mayo Clinic proceedings 2013; 88: 720-755.

5. Song $Y$, Wang $L$, Pittas AG, Del Gobbo LC, Zhang C, Manson JE, HU FB. Blood 25-hydroxy vitamin $\mathrm{D}$ levels and incident type 2 diabetes: a meta-analysis of prospective studies. Diabetes Care 2013; 36: 14221428.

6. Mitri J, Muraru MD. Pittas AG. Vitamin D and type 2 diabetes: a systematic review. Eur J Clin Nutr 2011; 65: 1005-1015.
7. Joergensen C, Gall ma, Schmedes A, Tarnow L, Parving HH, Rossing P. Vitamin D levels and mortality in type 2 diabetes. Diabetes Care 2010; 33: 2238-2243.

8. Grimnes G, Emaus N, Joakimsen RM, Figenschau Y, Jenssen T, Njolstad I, Schirmer H, Jorde R. Baseline serum 25-hydroxyvitamin D concentrations in the Tromso Study 1994-95 and risk of developing type 2 diabetes mellitus during 11 years of follow-up. Diabet Med 2010; 27: 1107-1115.

9. Pittas AG, Lau J, Hu FB, Dawson-Hughes B. The role of vitamin D and calcium in type 2 diabetes. A systematic review and metaanalysis. J Clin Endocrinol Metab 2007; 92 : 2017-2029.

10. Lebovitz HE. Adjunct therapy for type $1 \mathrm{di}$ abetes mellitus. Nat Rev Endocrinol 2010; 6: 326-334.

11. Lutz TA, Meyer U. Amylin at the interface between metabolic and neurodegenerative disorders. Front Neurosei 2015; 9: 216. doi: 10.3389/fnins.2015.00216. eCollection 2015.

12. Braun TR, Been LF, Blackett PR, Sanghhera DK. Vitamin D Deficiency and Cardio-Metabolic Risk in a North Indian Community with Highly Prevalent Type 2 Diabetes. J Diabetes Metab 2012; 3: doi; 10.4172/21556156.1000213.

13. Mirhosseini $N$, Vatanparast $H$, Mazidi $M$, Kimball SM. The effect of improved serum 25-hydroxyvitamin D status on glycemic control in diabetic patients: a meta-analysis. J Clin Endocrinol Metab 2017; 102: 3097-3110.

14. Fondjo LA, Owiredu WKBA, Sakyi SA, Laing E F, Adotey-Kwofie MA, Antoh EO, Detoh E. Vitamin D status and its association with insulin resistance among type 2 diabetics: A case -control study in Ghana. PloS one 2017; 12: e0175388-e0175388.

15. Vanlint S. Vitamin D and obesity. Nutrients 2013; 5: 949-956.

16. Shoelson SE, Lee J, Goldfine AB. Inflammation and insulin resistance. J Clin Invest 2006; 116: 1793-1801.

17. Azizieh F, Alyahya KO, Raghupathy R. Association between levels of vitamin $\mathrm{D}$ and inflammatory markers in healthy women. $\mathrm{J}$ Inflamm Res 2016; 9: 51-57. 
18. Holick MF. The D-lightful vitamin D for child health. J Parenter Enteral Nutr 2012; 36: 9-19.

19. Wobke TK, Sorg BL, Steinhilber D. Vitamin D in inflammatory diseases. Front Physiol 2014; 2(5):244. doi: 10.3389/ fphys.2014.00244.

20. Pittas AG, Dawson-Hughes B, Sheehan P, Ware JH, Knowler WC, Aroda VR, Brodsky I, Ceglia L, Chadha C, Chatterjee R, Desouza C, Dolor R, Foreyt J, Fuss P, Ghazi A, Hsia DS, Johnson KC, Kashyap SR, Kim S, LeBlanc ES, Lewis MR, Liao E, Neff LM, Nelson J, O’Neil P, Park J, Peters A, Phillips LS, Pratley R, Raskin P, Rasouli N, Robbins D, Rosen C, Vickery EM, State M. Vitamin D supplementation and prevention of type 2 diabetes. N Engl J Med 2019;381(6):520-530.

21. Talaei A, Mohamadi M, Adgi $Z$. The effect of vitamin $\mathrm{D}$ on insulin resistance in patients with type 2 diabetes. Diabetol Metab Syndr 2013;26;5(1):8. doi: 10.1186/17585996-5-8.

22. Chen WJ, Santini F, Carnevale G, Chen JN, Liu SH, Lavoué S, Mayden R. New insights on early evolution of spiny-rayed fishes(Teleostei: Acanthomorpha). Front Mar Sci 2014; vol 1, article 53. doi: 10.3389/ fmars.2014.00053

23. Razzaghi R, Pourbagheri H, Momen-Heravi M, Bahmani F, Shadi J., Soleimani Z, Asemi Z. The effects of vitamin D supplementation on wound healing and metabolic status in patients with diabetic foot ulcer: A randomized, double-blind, placebocontrolled trial. J Diabetes Complications 2017; 31: 766-772.

24. Sun X, Cao ZB, Tanisawa K, Ito T, Oshima S, Higuchi M. Vitamin D supplementation reduces insulin resistance in Japanese adults: a secondary analysis of a doubleblind, randomized, placebo-controlled trial. Nutr Res 2016; 36: 1121-1129.

25. Salehpour A, Shidfar F, Hosseinpanah F, Vafa M, Razaghi M, Amiri F. Does vitamin D3 supplementation improve ǵlucose homeostasis in overweight or obese women? A double-blind, randomized, placebo-controlled clinical trial. Diabet Med 2013; 30: 1477-1481.

26. DE Medeiros Cavalcante IG, Silva AS, Costa MJ, Persuhn DC, Issa CT, DE Luna
FTL, DA Conceicao RGM. Effect of vitamin D3 supplementation and influence of BsmI polymorphism of the VDR gene of the inflammatory profile and oxidative stress in elderly women with vitamin $\mathrm{D}$ insufficiency: Vitamin D3 meǵadose reduces inflammatory markers. Exp Gerontol 2015; 66: 10-6.

27. Wu S, Liao AP, Xia Y, Li YC, Li JD, Sartor RB, Sun J. Vitamin D receptor negatively regulates bacterial-stimulated NF-kappaB activity in intestine. Am J Pathol 2010; 177 : 686-697.

28. Chen CD, Sloane J, Li H, Aytan N, Giannaris E, Zeldich E, Hinman J, Dedeoglu A, Rosene D, Bansal R, Luebke J, Kuro-O M, Abraham, RC. The anti-aging protein klotho enhances oligodendrocyte maturation and myelination of the general nervous system. J Neurosei 2013;33(5): 1927-1939. doi: 10.1523/JNEUROSCI.2080-12.2013.

29. Sun J, Kong J, Duan Y, Szeto FL, Liao A, Madara JL, Li YC. Increased NF-kappaB activity in fibroblasts lacking the vitamin D receptor. Am J Physiol Endocrinol Metab 2006; 291: E315-322.

30. Matias PJ, Jorge C, Ferreira C, Borges M, Aires I, Amaral T, Gil C, Cortez J, Ferreira A. Cholecalciferol supplementation in hemodialysis patients: effects on mineral metabolism, inflammation, and cardiac dimension parameters. Clin J Am Soc Nephrol 2010; 5: 905-911.

31. Sepehrmanesh Z, Kolahdooz F, Abedi F, Mazroii N, Assarian A, Asemi Z, Esmaillzadeh A. Vitamin D supplementation affects the Beck depression inventory, insulin resistance, and biomarkers of oxidative stress in patients with major depressive disorder: A randomized, controlled clinical trial. J Nutr 2016;146(2):243-248. doi: 10.3945/ jn.115.218883. Epub 2015 Nov 25.

32. Witham MD, Dove FJ, Khan f, Lang CC, Belch JJ, Struthers AD. Effects of vitamin D supplementation on markers of vascular function after myocardial infarction--a randomised controlled trial. Int J Cardiol 2013; 167: 745-749.

33. Pittas AG, Lau J, Hu FB, Dawson-Hughes B. The role of vitamin $D$ and calcium in type 2 diabetes. A systematic review and metaanalysis. J Clin Endocrinol Metab 2007; 92 : 2017-2029.

Vol. 60(4): 310 - 318, 2019 
34. Maestro B, Molero S, Bajo S, Davila N, Calle C. Transeriptional activation of the human insulin receptor gene by 1,25-dihydroxyvitamin D(3). Cell Biochem Funct 2002; 20: 227-232.
35. Panero F, Novelli G, Zuceo C, Fornengo P, Perotto M, Segre O, Grassi G, Cavallo-Perin P, Bruno G. Fasting plasma C-peptide and micro- and macrovascular complications in a large clinic-based cohort of type 1 diabetic patients. Diabetes Care 2009; 32: 301-305. 